\title{
Assessing perceptions regarding distributive justice in the South African financial services industry
}

\section{Authors: \\ Prof. Elroy E. Smith ${ }^{1}$ \\ Prof. Noxolo E. Mazibuko \\ Dr Viwe Mrwebi \\ Affiliation: \\ ${ }^{1}$ Nelson Mandela University, Port Elizabeth, South Africa \\ ${ }^{2}$ Vaal University of Technology, Vanderbijlpark, South Africa}

\section{Corresponding author: \\ Prof. Elroy E. Smith \\ elroy.smith@mandela.ac.za \\ DOI:}

10.15249/13-1-206

\section{Keywords:}

distributive justice; fairness; financial services firms; organisational justice; perceptions

\section{Abstract}

Distributive justice is associated with the perceptions of an individual of the presence of equity and fairness in an organisation and how employees compare their expectations to the actual outcome. The primary objective of this article is to critically assess distributive justice within the South African financial services industry. A quantitative research design was employed. Non-probability sampling was used and 436 usable questionnaires were returned. The empirical results revealed that trustworthiness of management, extrinsic rewards and organisational climate have a positive influence on distributive justice, while employee engagement and two-way communication were found to have no significant influence on distributive justice. Furthermore, distributive justice had a positive influence on organisational citizenship behaviour and reputable employee retention in the financial services industry.

\section{Introduction}

Organisational justice has captured the attention of scholars in recent years (see, for example, Gomes, Mellahi, Sahadev \& Harvey, 2017:582; Lather \& Kaur, 2017). Most organisational justice literature identifies three types or dimensions of organisational justice namely, procedural, distributive and interactional justice (see, for example, Greenberg \& Baron, 2008:45; Sjahruddin, Sudiro \& Normijati, 2013:138; Yean \& Yusof, 2016). The focus of this article will only be on distributive justice in the financial services industry. It is associated with the perceptions and reactions of an individual to the presence of fairness in an organisation and captures what that individual feels or evaluates to be morally correct rather 
than viewing it as something prescriptive (Whiteside, 2015:2). Although Ledimo (2015:27) argues that measuring organisational justice in a South African context is a concern, as the concept is multi-dimensional and there is no comprehensive definition, limited research was found on distributive justice, specifically in the financial services industry. Kim and Park (2017) are also of the opinion that research on organisational justice found that employee perceptions about justice are related to various organisational outcomes (e.g. job satisfaction, trust, organisational commitment, and organisational citizenship behaviours).

The South African financial services industry is one of the fastest-growing industries and the largest contributor to GDP with a contribution of 20\% (StatsSA, 2017). However, scandals in recent years exposed a number of weaknesses in financial systems characterised by many illegal or unethical activities that came at an enormous cost to society and resulted in a significant loss of public trust in financial services as a whole (Bikhani, 2017:19). Crawshaw, Cropanzano, Bell and Nadisic (2013:885) further argue that a significant growth in theoretical and empirical research has begun to integrate how ethics might influence the administration of justice or fairness or how experiences of (in)justice motivate ethical or unethical behaviours.

In addition, since the financial services industry is composed of a diverse group of employees, several characteristics of financial services, as compared to other organisational behaviour settings, suggest the need to examine organisational justice in this context (Butt \& Atif, 2015:36). Against this background, this study will thus focus on the nature, extent and impact of organisational justice, with specific reference to distributive justice within the financial services industry in South Africa.

\section{Problem statement}

Shah, Anwar and Irani (2017:240) postulate that a feature of the global economic and financial crisis has been that many organisations were faced with the hurdle of downsizing and occasional collapse as a result of unethical behaviour by some of their employees. Buys and Van Niekerk (2014:110) postulate that the financial services industry plays a critical role in the economic development and growth of the country, yet the problem within the industry is that managers and employees are not fully conversant with what constitutes organisational justice and injustice, which creates an environment of misunderstanding that is not conducive for effective work relations. Lown, Osler, Strahan and Sufi (2000) are also of the opinion that managers and supervisors in the financial services industry often create a platform of favouritism and employees display negative attitudes towards their job and the organisation. These perceived injustices such as favouritism, nepotism, unfair dismissal and tokenism create a situation where employees perceive themselves as being unjustly treated. Furthermore, other perceived injustices, which can be clearly attributed to a distributive unjust organisation, are propelled by a situation where employees with the same job and responsibilities are paid and rewarded unequally. This could create tension amongst workers. These employees often retaliate 
by displaying negative attitudes (Botha, 2015:34). According to Wan (2017), perceptions of organisational justice are widely recognised as an influential factor in employee attitudes and behaviours in the workplace.

Rupp, Wright, Aryee and Luo (2015:15) concur that values and norms about what is considered fair and ethical underlie how individuals perceive and evaluate the behaviours and decisions of others, and also drive the reactions (or sanctions) against those who violate them. Although three main types of organisational justice are identified in the literature (see, for example, Srivastava, 2015:666; Cropanzano, Bowen \& Gilliland, 2007:34), namely distributive, procedural and interactional justice, this article focuses only on distributive justice. This led to the following main research question to be addressed in this study: What is the nature and extent of organisational justice, with specific reference to distributive justice, within the financial services industry in South Africa?

\section{Research objectives}

The primary objective of this article is to analyse the perceptions regarding distributive justice within the South African financial services industry. The secondary research objectives are identified as:

- To critically review the literature pertaining to distributive justice;

- To identify the factors that could impact on distributive justice;

- To empirically assess the views of employees and managers with regard to distributive justice in the South African financial services industry; and

- To provide guidelines in terms of how distributive justice can be effectively implemented and improved in the South African financial services industry.

\section{Theoretical overview of organisational justice}

\subsection{Clarification of key concepts}

Moliner, Cropanzano and Martínez-Tur (2017) state that organisational justice refers to how an employee judges the behaviour of the organisation and the employees' resulting attitudes and behaviour towards perceived fairness. It refers to employees' perceptions of the fairness of decision-making and decision-making processes and the influences of these perceptions on workplace behaviour (Colquitt \& Zipay, 2015). Muchinsky (2003:314) further explains that organisational justice concerns itself with the fair treatment of people within organisations. It can be regarded as a limited form of social justice that can be defined as fair and proper administration of laws that conform to the natural law that all persons should be treated without prejudice, irrespective of factors such as ethnic origin, gender, possession, race and religion, amongst others. Fairness can be questioned both in the processes followed as well as in decisions being made. Organisational justice could be divided into three distinct dimensions, namely, distributive, procedural and interactional 
justice, which is further divided into interpersonal and informational justice (Greenberg \& Baron, 2008:44). This article will focus only on distributive organisational justice.

\subsubsection{Distributive justice}

Distributive justice is primarily concerned with how the outcomes of the organisation are divulged in terms of creating fairness (Maiese, 2013:51). It thus relates to the degree to which decisions by managers are perceived as fair in terms of distribution and allocation of outcomes, for example, promotions and salaries. It also relates to the degree to which managerial decisions allocate rewards in an equitable and fair manner to employees (Lamont, 2017). Distributive justice focuses on people's belief that they have received a fair amount of pay and recognition in relation to exerted effort which could have a great impact on employees' work satisfaction and motivation levels when equal pay is justly distributed.

\subsubsection{Procedural justice}

Procedural justice refers to the means by which outcomes are allocated but not specifically to the outcomes themselves, by establishing certain principles specifying and governing the role of participants during the decision-making process (Niehoff \& Moorman, 2010:356). Procedural justice thus refers to the degree of fairness that is exercised during the process of making decisions or creating procedures, and relates to perceptions that affect employees and the degree to which fair methods and guidelines are used when allocation decisions are made (Drahos, 2017:46). Procedural justice and employees' perceptions of fairness of the procedures can be improved if employees are afforded an opportunity to voice their views in the decision-making process.

\subsubsection{Interactional justice}

Rani, Garg and Rastogi (2012:185) state that interactional justice focuses on how employees are treated during the decision-making process and thus the quality of the interpersonal interaction between the employees and the employers in an organisation. According to Ololube (2016:432), there are two aspects of interactional justice. The first part is called informational justice and refers to whether one is truthful and provides adequate justifications when things go wrong. The second part is called interpersonal justice and refers to the respect and dignity with which one treats others.

\subsection{Evolution of distributive justice movement}

The distributive justice movement emanated and can be traced back to the 1950s and is primarily concerned with equity in the allocation of resources. The matter of distributive justice, which concerns itself with the allocation of resources, has been a major concern for social scientists for decades (Lather \& Kaur, 2015:7-25).

Attention to social comparison was created whereby people's responses were seen as primarily dependent upon the comparison with the outcomes of others against whom people judge themselves and less on the absolute levels of their own outcomes 
(Festinger, 1954:120). Distributive justice was perceived as that of establishing the importance of social comparison processes in judging satisfaction with outcomes.

The social exchange process emanated from Homans (1961) and is defined as the process by which one person acts in accordance with the reaction of another. It is envisaged that individuals involved in the social exchange processes and relationships have perceptions regarding the possibility that one party may be getting more benefit from the exchange compared to the other one. Distributive injustice arises when the returns are less than the investment, which results in resentment, anger and bitterness.

The equity theory, developed in 1963 by Adams, also played an important role in contributing to the organisational justice concept. Equity theory focuses on determining whether the distribution of resources is fair to both relational partners. Equity is measured by comparing the ratio of contributions (or costs) and benefits (or rewards) for each person. It was envisaged that people relate their outcomes to the corresponding ratios of other people (Hatfield, Salmon \& Rapson, 2011:101). In advocating the uses of alternative allocation norms, Leventhal, Karuza and Fry (1980) significantly broadened the scope and definition of distributive justice. This means that fair outcomes are determined and result in allocation norms that benefit the achievement of key goals. It is therefore clearly described that the acknowledgements of allocation decisions should be described more accurately amongst the multiple allocation norms.

\subsection{Perspectives on distributive justice}

Distributive justice is a concept that addresses the ownership of goods in a society. It assumes that there is a large amount of fairness in the distribution of goods. Equal work should provide individuals with an equal outcome in terms of goods acquired or the ability to acquire goods. Distributive justice is absent and unfairness is perceived when equal work does not produce equal outcomes or when an individual or a group acquires a disproportionate amount of goods (Dutton \& Ragins, 2017). The definition of distributive justice shows that there are three principles involved as indicated below.

\subsubsection{Equality}

Equality ensures that every member of society has a basic number of goods regardless of how much work they have done or executed in terms of realising organisational goals (Thompson, 2018:5). According to O'Brien (2017:6), equality affects two areas of distributive justice, namely opportunities and outcomes. Equality of opportunity is found when all members of a society are allowed to participate in acquiring goods. However, equality of outcome is more relative and does not guarantee that all members of a society will receive the same number of goods. It does guarantee that equal work will produce an equal amount of goods.

\subsubsection{Proportionality}

Proportionality is similar to the equality of outcome. It is based on the idea that equal work produces equal outcomes. It is found more often in relative circumstances. If two 
workers performed the exact same job for the exact same length of time (with a similar amount of experience), then, if distributive justice is at play, both workers will be able to acquire the same amount of goods (Haydin, 2018).

\subsubsection{Fairness}

Fairness is defined as just and reasonable treatment in accordance with accepted rules or principles. Treating all people equally and applying reasonable punishments only when rules are broken, is an example of fairness (Resher, 2018). Carter, Mossholder and Harris (2018), state that fairness in the workplace is about respecting, and advancing, the human rights of all employees. Businesses can only flourish in societies in which human rights are respected, advanced and upheld.

Cropanzano and Ambrose (2001:135) propose that the employee will compare his or her expectations to the actual outcomes to exercise judgement. Employees will feel that the outcome was fair if his or her expectations have been met or exceeded. Yet, when expectations have been violated and the outcomes fall short of what was anticipated he/she will experience a sense of injustice. Procedures in which people are treated differently are usually considered unfair. Muchinsky (2003:316) warns that these types of disagreements on what is fair or unfair are not uncommon. The organisation should typically seek to gain consensus regarding which rule is the fairest to follow when distributing rewards. Perceptions of fairness play an important role in an employee's decisions to co-operate. Anik, Aknin, Norton and Dunn (2009) state that perceptions are formed whether the procedure and the distribution process are fair or not. The manner in which the distribution is made and the final outcome is evaluated by the individual. Socio-emotional benefits are symbolic and are concerned with an individual's identification, standing and status within a group.

\section{Proposed hypothetical model and hypotheses of the study}

The hypothetical model of this study was based on three previous studies and models of organisational justice namely, Lavelle, Rupp and Brockner (2007); Kang's model (2007) and Rupp's model (2011).

Lavelle et al. (2007:852) developed a multi-foci approach to justice, social exchange and citizenship behaviour and opine that employees use multiple parties to create perceptions of organisational justice. These assessments will impact on the level of social exchange between the employee and a particular party and are more likely to reciprocate feelings of justice and social exchange by directing their attitude and behaviours to the focal party. Distributive justice is embedded in the model for social exchange, which can affect relationships and effectively predict organisationally-directed outcomes and organisational identification. 
Kang's (2007:90) organisational justice model postulates that employee justice perceptions are a predictor of their motivation to participate in training (Konovsky \& Cropanzano, 1993:701). Perceptions of employees' justice are perceived as benefits of training that affect employee motivation to participate in training activities. Organisational justice can effectively predetermine the willingness of employees to effectively participate in training programmes.

Rupp's (2011:81) justice process model postulates that employees are confronted with work-related events on a daily basis. The experience of these events creates various psychological processes. The formation of justice judgements and holding others accountable for unjust acts and development of relationships is critical for those parties that are accountable for justice-related events and development of employees' subsequent attitudinal and behavioural responses. The proposed hypothetical model of this study, representing the various relationships or factors influencing distributive justice in the South African financial services industry and the perceived outcomes, is depicted in Figure 1.

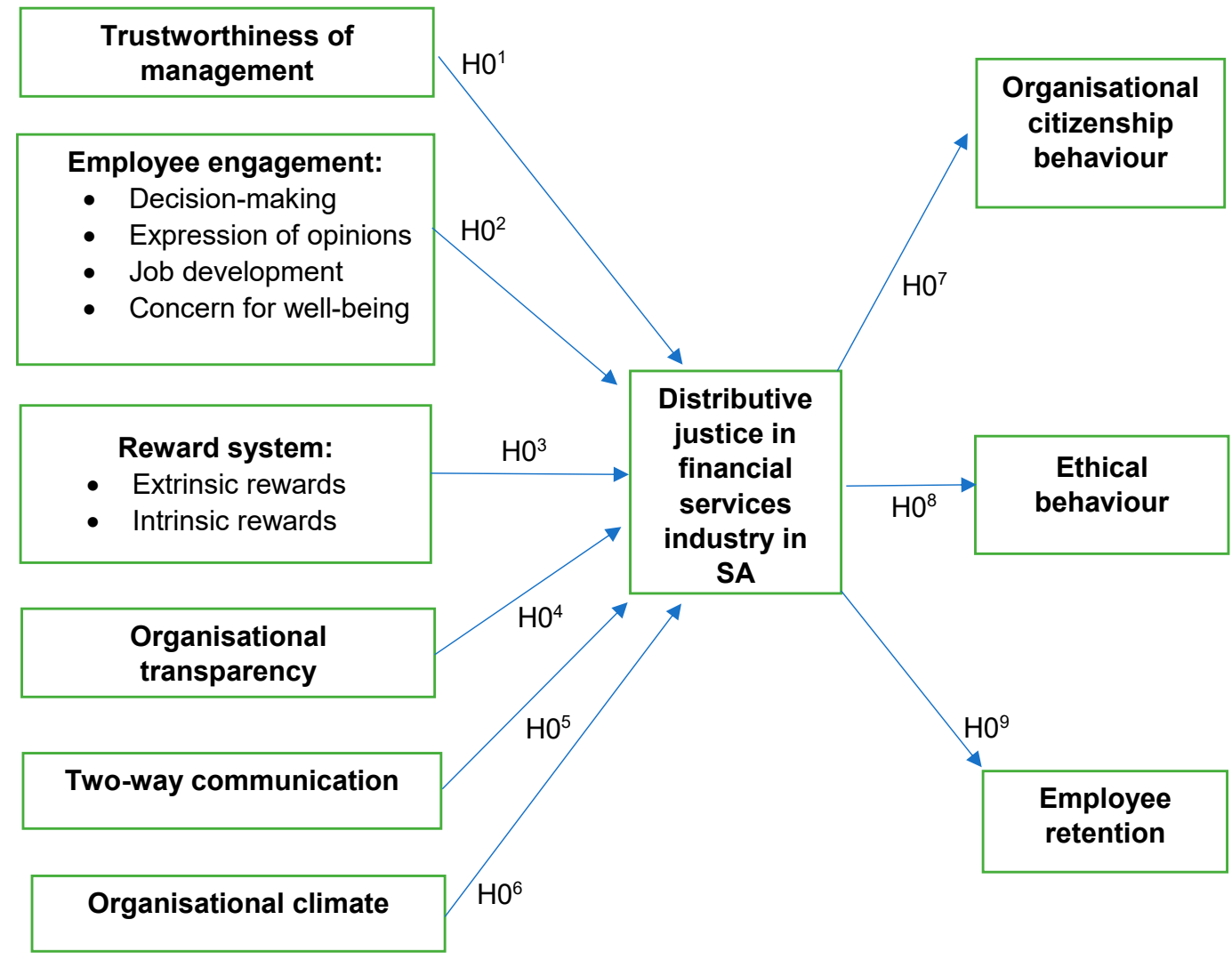

Figure 1: Proposed hypothetical model 
The following null-hypotheses are to be addressed in this article.

a) First set of hypotheses: Relationships between the independent variables and the mediating variable

- $\mathrm{H} 0^{1}$ : Trustworthiness of management does not influence distributive justice in the financial services industry.

- $\mathrm{H} 0^{2}$ : Employee engagement (as measured by involvement in decision-making, expression of opinions, job development and concern for well-being) does not influence distributive justice in the financial services industry.

- $\mathrm{H} 0^{3}$ : Reward systems (as measured by extrinsic and intrinsic rewards) do not influence distributive justice in the financial services industry.

- $\mathrm{H} 0^{4}$ : Organisational transparency does not influence distributive justice in the financial services industry.

- $\mathrm{H} 0^{5}$ : Two-way communication does not influence distributive justice in the financial services industry.

- $\mathrm{H} 0^{6}$ : Organisational climate (as measured by supervisory style and organisational support) does not influence distributive justice in the financial services industry.

b) Second set of hypotheses: Relationships between the mediating variable and the dependent variables (outcomes)

- $\mathrm{H} 0^{7}$ : Distributive justice does not influence organisational citizenship behaviour in the financial services industry.

- $\mathrm{H} 0^{8}$ : Distributive justice does not influence ethical behaviour in the financial services industry.

- $\mathrm{H} 0^{9}$ : Distributive justice does not influence employee retention in the financial services industry.

\section{Operationalisation of study variables and scale development}

Table 1 outlines the operationalisation of the study variables used in the conceptual model and the scale development of the measuring instrument.

Table 1: Operationalisation of study variables and scale development of measuring instrument

\begin{tabular}{|l|c|l|}
\hline Operationalisation of factors & $\begin{array}{l}\text { No. of } \\
\text { items }\end{array}$ & Authors/Sources \\
\hline $\begin{array}{l}\text { Trustworthiness refers to the propensity to } \\
\text { become vulnerable with respect to another } \\
\text { party. A socially confirmed expectation to deal } \\
\text { with all pertinent issues and strategic goals. }\end{array}$ & 5 & $\begin{array}{l}\text { Cropanzano et al. (2007); } \\
\text { Haliru \& Mokhtar (2015); } \\
\text { Rawlins (2008); } \\
\text { Reiche, Cardona, Lee \& Canela (2014); } \\
\text { Roy, Devlin \& Sekhon (2015) }\end{array}$ \\
\hline
\end{tabular}




\begin{tabular}{|c|c|c|}
\hline Operationalisation of factors & $\begin{array}{l}\text { No. of } \\
\text { items }\end{array}$ & Authors/Sources \\
\hline $\begin{array}{l}\text { Employee engagement refers to the mutual } \\
\text { commitment between employers and } \\
\text { employees to do things to help one another } \\
\text { to achieve goals and aspirations. }\end{array}$ & 12 & $\begin{array}{l}\text { Al-Tit \& Hunitie (2015); } \\
\text { Lavelle et al. (2007); } \\
\text { Markos \& Sridevi (2010); } \\
\text { Pettigrew (2014) }\end{array}$ \\
\hline $\begin{array}{l}\text { Reward system refers to all monetary and } \\
\text { non-monetary compensation and incentives } \\
\text { provided by the firm to employees in return } \\
\text { for their contributions in terms of their physical } \\
\text { and mental effort. This includes extrinsic and } \\
\text { intrinsic rewards. }\end{array}$ & 10 & $\begin{array}{l}\text { Kang (2007); } \\
\text { Khan, Shalid, Nawab \& Wali (2013); } \\
\text { Rubina, Umar \& Fahad (2013); } \\
\text { Snelgar, Renard \& Venter (2013); } \\
\text { Yasmeen, Farooq \& Asghar (2013:938) }\end{array}$ \\
\hline $\begin{array}{l}\text { Organisational transparency can be defined } \\
\text { as an ability to divulge information to its } \\
\text { employees in order to create an effective } \\
\text { understanding between the organisation and } \\
\text { its employees. }\end{array}$ & 5 & $\begin{array}{l}\text { Rupp (2011); } \\
\text { Schnakenberg \& Tomlinson (2016); } \\
\text { Sturges (2007) }\end{array}$ \\
\hline $\begin{array}{l}\text { Two-way communication refers to sending } \\
\text { the message and feedback between the } \\
\text { sender and the receiver by employing tools } \\
\text { of persuasion and negotiation. }\end{array}$ & 5 & $\begin{array}{l}\text { Lavelle et al. (2007); } \\
\text { Morsing \& Schultz (2006); } \\
\text { Taran \& Gächter (2012); } \\
\text { Versosa \& Garcia (2009) }\end{array}$ \\
\hline $\begin{array}{l}\text { Organisational climate refers to conditions } \\
\text { within an organisation as viewed by its } \\
\text { employees and usually describes practices } \\
\text { involved in communication, conflict, leadership } \\
\text { and rewards. }\end{array}$ & 5 & $\begin{array}{l}\text { Cojocaru \& Stoican (2010); } \\
\text { Cooper, Cartwight \& Earley (2001); } \\
\text { Kang (2007); } \\
\text { Lavelle et al. (2007); } \\
\text { Martins \& Von der Ohe (2003); } \\
\text { Noordin, Omar, Sehan \& Idrus (2010); } \\
\text { Rhoades \& Eisenberger (2002); } \\
\text { Rupp (2011:81); } \\
\text { Schneider, Erhart \& Macey (2013) }\end{array}$ \\
\hline $\begin{array}{l}\text { Organisational citizenship behaviour } \\
\text { describes an employee's commitment within } \\
\text { an organisation that is not part of his or her } \\
\text { contractual tasks and is usually discretionary } \\
\text { in nature. }\end{array}$ & 5 & $\begin{array}{l}\text { Crawshaw et al. (2013); } \\
\text { Konovsky \& Pugh (1994); } \\
\text { Lavelle et al. (2007); } \\
\text { Mooroman (1991); } \\
\text { Organ, Podsakoff \& Mackenzie (2006); } \\
\text { Podsakoff \& Mackenzie (2012) }\end{array}$ \\
\hline $\begin{array}{l}\text { Ethical behaviour refers to acting in ways } \\
\text { consistent with what society and individuals } \\
\text { typically think are good values and moral } \\
\text { principles that include honesty, fairness, } \\
\text { equality, dignity, diversity and individual rights. }\end{array}$ & 5 & $\begin{array}{l}\text { De Cremer, Mayer \& Schminke (2010); } \\
\text { Rupp (2011); } \\
\text { Treviño, Butterfield \& MacCabe (2001); } \\
\text { Trevino, Weaver \& Reynolds (2006) }\end{array}$ \\
\hline $\begin{array}{l}\text { Employee retention refers to a voluntary move } \\
\text { by an organisation to create an environment } \\
\text { which engages the employee for the long } \\
\text { term with the purpose of preventing loss of } \\
\text { competent employees from the organisation. }\end{array}$ & 5 & $\begin{array}{l}\text { Hausknecht, Rodda \& Howard (2009); } \\
\text { Nwokocha \& Iheriohanma (2012); } \\
\text { Rupp (2011); } \\
\text { Samuel \& Chipunza (2009); } \\
\text { Smit \& Cronje (2002); } \\
\text { Veloso et al. (2014) }\end{array}$ \\
\hline $\begin{array}{l}\text { Distributive justice refers to the role in the } \\
\text { workplace and employees' perceptions of } \\
\text { fairness in decision-making and processes } \\
\text { which influence the workplace behaviour. }\end{array}$ & 5 & $\begin{array}{l}\text { Colquitt \& Rodell (2011); } \\
\text { Cropanzano \& Ambrose (2001); } \\
\text { Cropanzano \& Greenberg (1997); } \\
\text { Kang (2007); } \\
\text { Niehoff \& Moorman (2010) }\end{array}$ \\
\hline
\end{tabular}




\section{Research design and methodology}

\subsection{Research paradigm}

The positivistic research paradigm is employed in this study and quantitative data are collected. Aspects of the social world and social phenomena are measured using a large set of data and statistical analysis.

\subsection{Research approach}

Given the nature of the study, the research approaches followed in this study are exploratory and descriptive in nature. The aim is to explore a relatively new area and describe respondents' perceptions regarding organisational justice in the South African financial services industry.

\subsection{Population and sampling}

The population of this study comprised all the financial services firms such as banking, insurance and financial accounting and auditing firms operating in South Africa within the four provinces of the Eastern Cape, Western Cape, Gauteng and KwaZulu-Natal. For the purposes of this study, a non-probability sampling technique is used, specifically convenience and judgemental sampling. The study aimed to gather responses from 800 employees of financial services firms from the four selected provinces in South Africa. Fieldworkers were instructed to obtain more or less an even amount of responses from employees and managers from banking, insurance and accounting and auditing firms within these four designated provinces. As these type of firms are mainly located in larger cities, Johannesburg, Pretoria, Cape Town, Port Elizabeth, Grahamstown, Durban and Bloemfontein were mainly targeted.

\subsection{Data collection}

According to Neuman (2003:160), data collection can be defined as the empirical evidence or information that one carefully gathers based on certain rules and procedures. Secondary data is composed of existing literature on organisational justice which forms the basis for the conceptual framework, upon which the frame of reference of the study was built. Secondary data sources for the literature review were obtained through conducting international and national data searches,through the use of journal articles, textbooks and the internet. The primary data for this study was obtained using the survey method by means of self-administered structured questionnaires. In this regard, the aim was to target 800 employees in financial services firms (200 employees from Eastern Cape, KwaZulu-Natal, Gauteng and Western Cape). A total of 436 usable questionnaires were obtained (effective response rate of 54\%). Ethical clearance was obtained before the empirical study was conducted. 
Questionnaires usually consist of a combination of factual and opinion-related questions. Self-administered structured questionnaires with closed-ended questions were used. The statements or questionnaire items were developed from existing scales and based on literature, as indicated in Table 1. A few items were self-developed by the researchers. The questionnaire consisted of four sections:

- Section A investigated the role of the independent variables (six factors) on distributive justice, using a seven-point ordinal Likert-type scale.

- Section $B$ analysed perceptions regarding distributive justice in the South African financial services firms according to a seven-point Likert scale.

- Section $C$ analysed the impact of distributive justice on the dependent variables (three outcomes) using a seven-point ordinal Likert-type scale.

- Section $D$ solicited the background information of the respondents (e.g. gender, age, ethnic group, educational background etc.), using nominal scale questions.

\subsection{Data analysis}

Data collected was transferred to an Excel spread sheet and analysed by means of the Statistica computer programme. Various statistical methods were used in this study. Descriptive statistics through measures of central tendency (mean) and dispersion (standard deviation) were used. Frequency distributions expressed as percentages were presented in the form of tables. Cronbach's alpha coefficients were used to assess the internal reliability of the study variables (cut-off point 0.80 ). Both face and content validity were assessed through a pilot study, expert judgement (management, ethics and statistical experts) and a thorough literature study. Exploratory factor analysis was used to assess construct validity. A cut-off point of 0.5 was used and at least three items should load per factor to be regarded as acceptable. Regression analysis was used to test relationships between the dependent and independent variables and to test the stated null-hypotheses of the study.

\section{Empirical results}

\subsection{Demographical profile of respondents}

The demographical profile of the respondents of the study is depicted in Table 2. For the purpose of this study, nine categorical or demographical variables were used. As this article forms part of a bigger study and organisational justice is a contemporary issue, it was deemed necessary to include these demographical variables to reflect diversity in the workplace. 
Table 2: Demographical profile of respondents

\begin{tabular}{|c|c|c|}
\hline Demographics & Range & $\%$ \\
\hline \multirow[t]{5}{*}{ Age } & Less than 20 & 11 \\
\hline & $21-30$ & 34 \\
\hline & $31-40$ & 36 \\
\hline & $41-50$ & 16 \\
\hline & $51-60$ & 3 \\
\hline \multirow[t]{2}{*}{ Gender } & Female & 58 \\
\hline & Male & 42 \\
\hline \multirow[t]{5}{*}{ Ethnic classification } & African & 60 \\
\hline & Coloured & 19 \\
\hline & Indian & 8 \\
\hline & White & 12 \\
\hline & Other & 1 \\
\hline \multirow[t]{6}{*}{ Highest qualification } & Grade 11 and lower & 2 \\
\hline & Grade 12 & 21 \\
\hline & Diploma or N-certificate & 28 \\
\hline & Bachelor's degree & 28 \\
\hline & Postgraduate degree/diploma & 21 \\
\hline & Other & 0 \\
\hline \multirow[t]{5}{*}{ Position in the organisation } & CEO/owner & 2 \\
\hline & Manager/supervisor & 17 \\
\hline & Employee & 64 \\
\hline & Professional & 10 \\
\hline & Other & 7 \\
\hline \multirow[t]{5}{*}{ Length of current employment (years) } & $1-5$ & 35 \\
\hline & $6-10$ & 25 \\
\hline & $11-15$ & 26 \\
\hline & $16-20$ & 11 \\
\hline & Above 21 & 3 \\
\hline \multirow[t]{3}{*}{ Employment size of organisation } & Small (less than 50) & 19 \\
\hline & Medium (51-199) & 52 \\
\hline & Large $(200+)$ & 28 \\
\hline \multirow[t]{4}{*}{ Years in existence of organisation } & $1-5$ years & 23 \\
\hline & $6-10$ years & 28 \\
\hline & $11-15$ years & 21 \\
\hline & 16 years + & 27 \\
\hline \multirow[t]{4}{*}{ Types of financial services industry } & Banking & 24 \\
\hline & Insurance & 36 \\
\hline & Accounting /auditing & 35 \\
\hline & Other & 5 \\
\hline
\end{tabular}


Exploratory factor loadings are depicted in Table 3. Overall factor analysis results regarding perceptions of employees about the independent variables, organisational justice and the dependent variables (outcomes) are presented. The focus of this article will, however, only be distributive justice. Factor loadings of greater than 0.50 were considered. The items refer to statements in the questionnaire that have loaded onto each variable.

Table 3: Empirical factor structure

\begin{tabular}{|l|l|l|l|}
\hline Latent variables/Factors & Items & $\begin{array}{c}\text { Minimum } \\
\text { loadings }\end{array}$ & $\begin{array}{l}\text { Maximum } \\
\text { loadings }\end{array}$ \\
\hline Trustworthiness of management (TM) & TM1, TM2, TM3, TM4, TM5 & 0.727291 & 0.858662 \\
\hline Employee engagement (EE) & $\begin{array}{l}\text { DM2, DM3, EO1, EO2, EO3, JD1, } \\
\text { JD2, JD3 }\end{array}$ & 0.516432 & 0.741926 \\
\hline Extrinsic rewards (EXT) & $\begin{array}{l}\text { EXT1, EXT2, EXT3, EXT4, CW1, } \\
\text { CW2, CW3 }\end{array}$ & 0.525848 & 0.717334 \\
\hline Intrinsic rewards (INT) & INT1, INT2, INT3, INT4, INT5 & 0.530590 & 0.673112 \\
\hline Organisational transparency (OT) & $\begin{array}{l}\text { OT1, OT2, OT3, OT4, OT5, TWC1, } \\
\text { TWC2 }\end{array}$ & 0.563910 & 0.702738 \\
\hline Organisational climate (OC) & $\begin{array}{l}\text { SS1, SS2, SS3, SS4, SS5, OS1, } \\
\text { OS2, OS3, OS4, OS5, TWC3, } \\
\text { TWC4, TWC5 }\end{array}$ & 0.506946 & 0.787994 \\
\hline Procedural- interactional justice (PIJ) & $\begin{array}{l}\text { PJ1, PJ2, PJ3, PJ4, PJ5, IJ1, IJ2, } \\
\text { IJ3, IJ4, IJ5 }\end{array}$ & 0.632194 & 0.772651 \\
\hline Distributive justice (DJ) & DJ1, DJ2, DJ3, DJ4, DJ5 & 0.637878 & 0.770535 \\
\hline Organisational citizenship behaviour (OCB) & $\begin{array}{l}\text { OCB1, OCB2, OCB3, OCB4, } \\
\text { OCB5 }\end{array}$ & 0.636218 & 0.885768 \\
\hline Reputable employee retention (RER) & $\begin{array}{l}\text { EB1, EB2, EB3, EB4, EB5, ER1, } \\
\text { ER2, ER3, ER4, ER5 }\end{array}$ & 0.562053 & 0.793370 \\
\hline
\end{tabular}

In Table 3, the first exploratory factor analysis conducted reveals that six independent (latent) variables could be identified, namely trustworthiness of management (TM), employee engagement (EE), extrinsic rewards (EXT), intrinsic rewards (INT), organisational transparency (OT) and organisational climate (OC). From the initial hypothetical model, rewards system loaded as two separate factors and two-way communication loaded onto organisational climate. Items which did not load to a significant extent $(p<0.05)$ were deleted and not used in subsequent analyses.

Table 3 further indicates that the respondents perceived organisational justice as a two-dimensional construct. All five items (PJ1, PJ2, PJ3, PJ4 and PJ5), which were meant to measure procedural justice and items which were meant to measure interactional justice (IJ1, IJ2, IJ3, IJ4 and IJ5) loaded onto one factor and are termed procedural-interactional justice (PIJ). All five items (DJ1, DJ2, DJ3, DJ4 and DJ5) intended to measure distributive justice loaded on a single factor (focus of this article). This implies that respondents view organisational justice as a two-dimensional concept. All five items (EB1, EB2, EB3, EB4 and EB5) which were meant to measure ethical behaviour and all five items which 
were meant to measure employee retention loaded and combined onto another factor and are termed 'Reputable employee retention'. All five items (OCB1, OCB2, OCB3, OCB4 and OCB5) loaded onto a single factor, namely organisational citizenship behaviour. New variables were formed as a result of the discriminant validity assessment with the exploratory factor analysis, thus the original theoretical model had to be adapted.

\subsection{Reliability of the measuring instrument}

Table 4 shows the Cronbach's alpha values of the latent variables.

Table 4: Cronbach's alpha coefficient of latent variables

\begin{tabular}{|l|l|c|}
\hline Latent variables/Factors & Items & $\begin{array}{c}\text { alpha } \\
\text { values }\end{array}$ \\
\hline Trustworthiness of management (TM) & TM1, TM2, TM3, TM4, TM5 & 0.92 \\
\hline Employee engagement (EE) & DM2, DM3, EO1, EO2, EO3, JD1, JD2, JD3 & 0.90 \\
\hline Extrinsic rewards (EXT) & EXT1, EXT2, EXT3, EXT4, CW1, CW2, CW3 & 0.90 \\
\hline Intrinsic rewards (INT) & INT1, INT2, INT3, INT4, INT5 & 0.88 \\
\hline Organisational transparency (OT) & OT1, OT2, OT3, OT4, OT5, TWC1, TWC2 & 0.91 \\
\hline Organisational climate (OC) & SS1, SS2, SS3, SS4, SS5, OS1, OS2, OS3, OS4, OS5, & 0.95 \\
\hline Distributive justice (DJ) & TWC3, TWC4, TWC5 & 0.89 \\
\hline Organisational citizenship behaviour (OCB) & OCB1, OCB2, OCB3, OCB4, OCB5 & 0.85 \\
\hline Reputable employee retention (RER) & EB1, EB2, EB3, EB4, EB5, ER1, ER2, ER3, ER4, ER5 & 0.93 \\
\hline
\end{tabular}

Table 4 indicates the Cronbach's alpha coefficients of the latent variables based on the comprehensive exploratory factor analysis. Furthermore, Table 4 summarises the items which are regarded as measures of individual variables in the theoretical model following the exploratory factor analyses. The study retains trustworthiness of management (TM), employee engagement (EE), extrinsic rewards (EXT), intrinsic rewards (INT), organisational transparency (OT), organisational climate (OC), distributive justice (DJ), organisational citizenship behaviour (OCB) and reputable employee retention (RER), as their Cronbach's alpha values were above the cut-off point. Table 5 indicates that all Cronbach's reliability coefficients are above 0.80 , which is regarded as acceptable for the purpose of this study.

\subsection{Descriptive statistics}

Descriptive statistical analysis involved the calculation of measures of central location such as the mean, as well as measures of variability such as standard deviations, as presented in Table 5.

Table 5: Descriptive statistics

\begin{tabular}{|l|c|c|}
\hline Variable & Mean & Standard deviation \\
\hline Trustworthiness of management (TM) & 5.13 & 1.17 \\
\hline Employee engagement (EE) & 5.10 & 1.02 \\
\hline
\end{tabular}




\begin{tabular}{|l|c|c|}
\hline Variable & Mean & Standard deviation \\
\hline Extrinsic rewards (EXT) & 5.10 & 1.14 \\
\hline Intrinsic rewards (INT) & 5.23 & 1.10 \\
\hline Organisational transparency (OT) & 5.25 & 1.09 \\
\hline Organisational climate (OC) & 5.21 & 1.03 \\
\hline Distributive justice (DJ) & 5.19 & 1.19 \\
\hline Organisational citizenship behaviour (OCB) & 5.00 & 1.29 \\
\hline Reputable employee retention (RER) & 5.36 & 1.03 \\
\hline
\end{tabular}

It appears that the mean values of all the variables cluster around point five (agree somewhat). Respondents thus agree to a certain extent that these six independent variables impact on distributive justice and result in these two outcomes (OCB and reputable employee retention). Reputable employee retention (RER) obtained the highest mean value and OCB the lowest mean value. It also appears that there is some variability around the mean scores (all above one). OCB obtained the highest standard deviations score.

\subsection{Regression analysis}

\subsubsection{The influence of trustworthiness of management, employee} engagement, extrinsic and intrinsic rewards, organisational transparency and organisational climate on distributive justice

Table 6 shows the regression analysis results of the influence of the independent variables on distributive justice in the financial services industry.

Table 6: Regression analysis: The influence of trustworthiness of management, employee engagement, extrinsic and intrinsic rewards, organisational transparency and organisational climate on distributive justice

\begin{tabular}{|l|c|c|c|c|c|c|}
\hline & \multicolumn{7}{c|}{ Regression summary for dependent variable: } \\
Distributive justice (DJ) \\
\hline \multicolumn{1}{|c|}{ Parameter } & Beta $b^{*}$ & Std Error & B & Std Error & T-value & P-value \\
\hline Trustworthiness of management (TM) & 0.176 & 0.044 & 0.180 & 0.045 & 3.963 & $0.001^{*}$ \\
\hline Employee engagement (EE) & -0.037 & 0.055 & -0.043 & 0.065 & -0.670 & 0.5032 \\
\hline Extrinsic rewards (EXT) & 0.205 & 0.056 & 0.213 & 0.058 & 3.656 & $0.001^{*}$ \\
\hline Intrinsic rewards (INT) & 0.039 & 0.059 & 0.043 & 0.064 & 0.671 & 0.5024 \\
\hline Organisational transparency (OT) & 0.090 & 0.062 & 0.098 & 0.068 & 1.452 & 0.147 \\
\hline Organisational climate (OC) & 0.336 & 0.059 & 0.386 & 0.067 & 5.707 & $0.001^{*}$ \\
\hline $\begin{array}{l}\mathrm{R}=68 \% \\
*=\mathrm{p}<0.001\end{array}$ & $\mathrm{~F}=59.905$ \\
\hline
\end{tabular}

Table 6 indicates that trustworthiness of management $(b=0.180, p<0.001)$ is positively related to distributive justice in the financial services industry. This indicates that management should make decisions in a fair manner in the organisation. Furthermore, extrinsic rewards $(b=0.213, p<0.001)$ is positively related to distributive justice in the financial services industry. This indicates that management should ensure that each 
employee's status in the hierarchical structure is satisfactory and is within the stage of their individual career. Table 6 shows that organisational climate as measured by supervisory style, organisational support and two-way communication $(b=0.386, p<0.001)$ is positively related to distributive justice in the financial services industry. This indicates that respondents feel that management should involve employees when decisions that affect them are made in their organisations. Also, respondents feel that management should commit themselves towards the career development of the employees.

Table 6 further indicates $\mathrm{R}^{2}$ of 0.456 and it explains $46 \%$ of variability in the model as explained by the moderating variable (distributive justice). Employee engagement as measured by decision-making, expression of opinions and job development $(r=-0.037, N S)$, intrinsic rewards $(r=0.039$, NS) and organisational transparency $(r=-0.090, N S)$ do not exert a significant influence on distributive justice in the financial services industry.

\subsubsection{The influence of distributive justice (DJ) on organisational citizenship behaviour and reputable employee retention (outcomes)}

Table 7 shows the regression analysis results of the influence of distributive justice (DJ) on organisational citizenship behaviour and reputable employee retention in the financial services industry.

Table 7: Regression analysis: Influence of distributive justice (DJ) on organisational citizenship behaviour and reputable employee retention

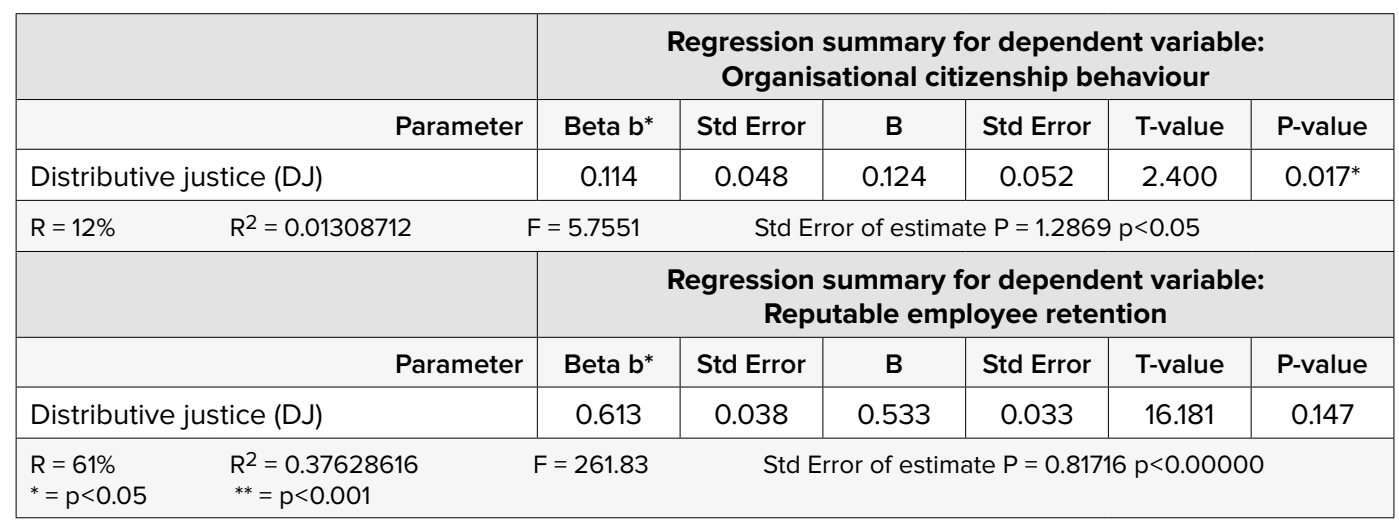

Table 7 shows that the $\mathrm{R}^{2}$ of 0.014 indicates that $1 \%$ of the variability in the model is explained by the variable 'Organisational citizenship behaviour'. Although distributive justice has a positive relationship with OCB $(b=0.124, p<0.05)$, this relationship is weak. This indicates that distributive justice is effectively practised when employees are more prepared to work extra time to complete urgent tasks in their jobs. Table 7 also shows that the $\mathrm{R}^{2}$ of 0.376 indicates that $37 \%$ of the variability in the model is explained by the variable 'Reputable employee retention'. This indicates that distributive justice has a positive relationship with reputable employee retention $(b=0.533, p<0.001)$. This means that distributive justice is effectively practised in the financial services industry when all employees are treated with respect and recognised and rewarded for their integrity in the organisation. As a result of the formulation of the adapted model, the original hypotheses had to be reformulated. 
Table 8 indicates the findings of the hypothesised relationships and renamed hypotheses.

Table 8: Findings of hypothesised relationships

\begin{tabular}{|c|c|c|}
\hline $\begin{array}{l}\text { No. of the } \\
\text { hypotheses }\end{array}$ & First set of hypothesis and renamed /new hypothesis & $\begin{array}{l}\text { Accepted/ } \\
\text { rejected }\end{array}$ \\
\hline $\mathrm{HO}^{1}$ & $\begin{array}{l}\text { Trustworthiness of management does not influence distributive justice in } \\
\text { the financial services industry. }\end{array}$ & Rejected \\
\hline $\mathrm{HO}^{2}$ & $\begin{array}{l}\text { Employee engagement (as measured by decision-making, expression of } \\
\text { opinions and job development) does not influence distributive justice in } \\
\text { the financial services industry. }\end{array}$ & Accepted \\
\hline $\mathrm{HO}^{3}$ & $\begin{array}{l}\text { Reward systems (as measured by extrinsic and intrinsic rewards) do not } \\
\text { influence organisational justice in the financial services industry. }\end{array}$ & \\
\hline $\mathrm{HO}^{3.1}$ & $\begin{array}{l}\text { Extrinsic rewards do not influence organisational justice related to } \\
\text { distributive justice in the financial services industry. }\end{array}$ & Rejected \\
\hline $\mathrm{HO}^{3.2}$ & $\begin{array}{l}\text { Intrinsic rewards do not influence distributive justice in the financial } \\
\text { services industry. }\end{array}$ & Accepted \\
\hline $\mathrm{HO}^{4}$ & $\begin{array}{l}\text { Organisational transparency does not influence distributive justice in the } \\
\text { financial services industry. }\end{array}$ & Accepted \\
\hline $\mathrm{HO}$ & $\begin{array}{l}\text { Two-way communication does not influence distributive justice in the } \\
\text { financial services industry. }\end{array}$ & Accepted \\
\hline $\mathrm{HO}^{6}$ & $\begin{array}{l}\text { Organisational climate does not influence distributive justice in the } \\
\text { financial services industry. }\end{array}$ & Rejected \\
\hline $\mathrm{HO}^{7}$ & $\begin{array}{l}\text { Distributive justice does not influence organisational citizenship } \\
\text { behaviour in the financial services industry }\end{array}$ & Rejected \\
\hline $\mathrm{HO}^{8}$ & $\begin{array}{l}\text { Distributive justice does not influence ethical behaviour in the financial } \\
\text { services industry }\end{array}$ & Accepted \\
\hline $\mathrm{HO}^{9}$ & $\begin{array}{l}\text { Distributive justice does not influence employee retention in the financial } \\
\text { services industry }\end{array}$ & Accepted \\
\hline $\mathrm{HO}^{10}$ & $\begin{array}{l}\text { Distributive justice does not influence reputable employee retention in } \\
\text { the financial services industry }\end{array}$ & Rejected \\
\hline
\end{tabular}

It is evident from Table 8 that reward systems $\left(\mathrm{H}^{3}\right)$ had to be renamed, as respondents viewed it as a two-dimensional concept of extrinsic and intrinsic rewards. Respondents also viewed ethical behaviour $\left(\mathrm{H}^{8}\right)$ and employee retention $\left(\mathrm{H}^{9}\right)$ as one concept and it was thus renamed as reputable employee retention. This could be visually illustrated by means of the revised model as indicated in Figure 2. 


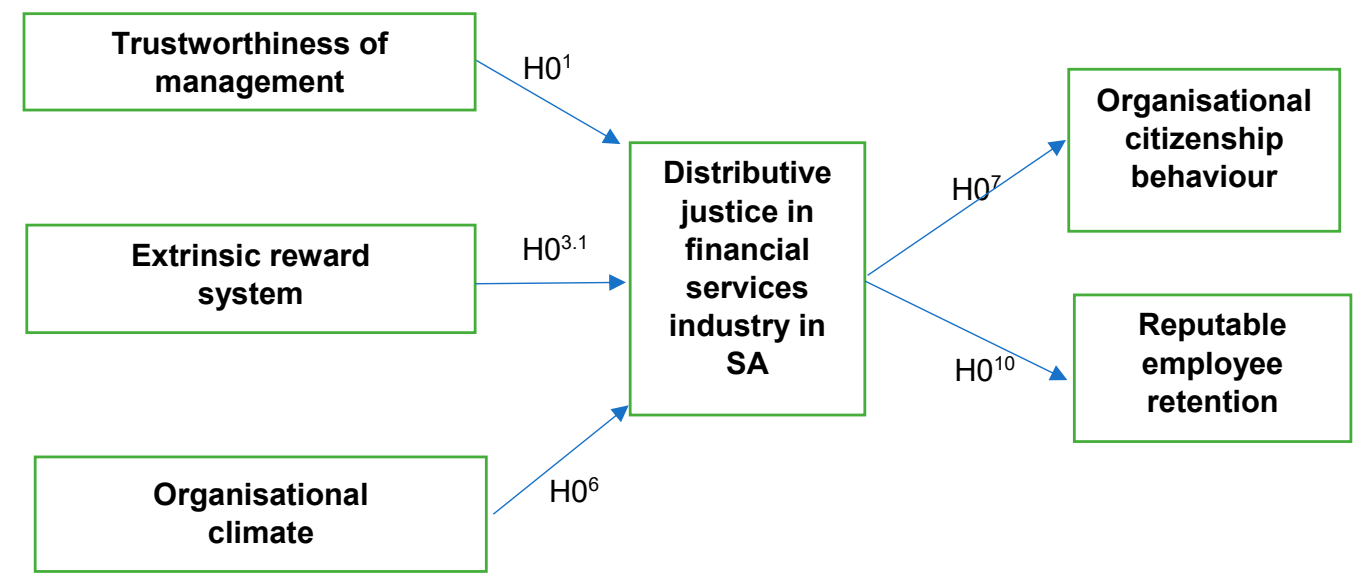

Figure 2: Revised hypothetical model

\section{Conclusions and managerial implications}

The empirical results of this study revealed that trustworthiness of management has a positive influence on distributive justice, as was also found by Saunders and Thornhill (2003) and Chory and Hubbell (2008). Respondents of this study viewed remuneration as a two-dimensional construct, namely extrinsic and intrinsic rewards. However, it appears that there is only a relationship between extrinsic rewards and distributive justice and these findings are consistent with Baer, Oldham and Cummings (2003:569) and Ajmal, Bashir, Abrar, Khan and Saqib (2015:470). The study findings also concur that organisational climate exerts a significant influence on distributive justice. These results are consistent with the study of Cooper, Cartwright and Early (2001) and Wayne, Shore, Bommer and Tetrick (2002).

It further appears that based on the empirical results of this study, employee engagement, intrinsic rewards and two-way communication have no significant influence on distributive justice in the financial services industry in South Africa. Furthermore, the empirical results showed that distributive justice has a positive influence on organisational citizenship behaviour, as was also supported by Nandan and Azim (2015). There also appears to be a significant relationship between distributive justice and reputable employee retention as was also suggested by Coldwell and Perumal (2007).

The empirical findings revealed that employees believe that distributive justice is effectively practised when their work schedule is fair in accordance with their job description and they are compensated according to the skills required for their jobs. This implies that employees believe that distributive justice is properly practised in the financial services industry when management is making decisions in a fair manner. Furthermore, employees believe that distributive justice is properly and meaningfully practised when recognition is based on the merit of each employee's performance and when promotion criteria are consistently applied equally to all employees. 
Thus, it is recommended that for distributive justice to be effective in the organisation, management should:

- Ensure that the work schedule of each employee is fair in accordance with individual job descriptions.

- Employ and compensate employees according to the skills required and acquired for their jobs.

- Make decisions, for example, pertaining to allocation and performance of work, in a fair manner.

- Base recognition on the merit of each employee's performance.

- Consistently apply promotion criteria equally to all employees.

- Ensure that equality of opportunity is found when all members of a society or an organisation are allowed to participate in acquiring goods or rewards.

- Facilitate that equality of outcomes are more relative and do not guarantee that all members will receive the same number of goods - guarantee that equal work will produce an equal amount of goods.

- Endorse the principle of proportionality whereby if two workers performed the exact same job for the exact same length of time (with a similar amount of experience), then both workers should be able to acquire the same amount of goods or rewards.

- Ensure just and reasonable treatment of all employees in accordance with accepted rules or principles by respecting and advancing the human rights of all employees. Businesses can only flourish in societies in which human rights are respected, advanced and upheld.

Table 9 highlights some general guidelines for implementing distributive justice practices, as suggested by the statements in the measuring instrument. These distributive justice practices in terms of the independent variables (factors impacting justice) and dependent variables (outcomes of distributive justice) are linked to the statements or items in the measuring instrument.

Table 9: General guidelines regarding distributive justice practices

\begin{tabular}{|c|l|}
\hline \multicolumn{1}{|c|}{ No. } & \multicolumn{1}{c|}{ Recommendations regarding: } \\
\hline 1 & $\begin{array}{l}\text { Influence of trustworthiness on distributive justice: Management should... } \\
\text { organisation. }\end{array}$ \\
\hline 2 & Always fulfil its promises made to all employees. \\
\hline 3 & Deal with employees in an honest and fair manner. \\
\hline 4 & Apply and implement authority with fairness and compassion. \\
\hline 5 & Follow organisational principles and procedures for successful execution of the job. \\
\hline & \multicolumn{1}{|c|}{ Influence of extrinsic rewards on distributive justice: Management should... } \\
\hline 6 & Reward all employees equally such as cash-based rewards and benefits. \\
\hline 7 & Actively interact with all employees regarding increment and performance bonuses. \\
\hline 8 & $\begin{array}{l}\text { Abide by the policies and principles of the organisations regarding the payment of employee } \\
\text { salaries. }\end{array}$ \\
\hline
\end{tabular}




\begin{tabular}{|c|c|}
\hline No. & Recommendations regarding: \\
\hline 9 & Offer a variety of effective wellness programmes for their employees. \\
\hline 10 & Offer sufficient flexibility to reconcile personal life with their jobs. \\
\hline \multicolumn{2}{|r|}{ Influence of organisational climate on distributive justice: Management should... } \\
\hline 11 & Involve employees when decisions that affect them are made. \\
\hline 12 & $\begin{array}{l}\text { Encourage collaboration between departments in order to promote the achievement of the stated } \\
\text { objectives. }\end{array}$ \\
\hline 13 & Show confidence in their subordinates by allowing them to work independently. \\
\hline 14 & Create a favourable environment for employees to socially interact with other colleagues. \\
\hline 15 & Commit themselves towards career development. \\
\hline \multicolumn{2}{|r|}{ Influence of distributive justice on organisational citizenship behaviour: Management should... } \\
\hline 16 & Inspire employees to be committed to complete tasks by walking the extra mile. \\
\hline 17 & $\begin{array}{l}\text { Inspire employees to attend social functions that are not officially required but could enhance the } \\
\text { organisation's image. }\end{array}$ \\
\hline 18 & Inspire employees to defend co-workers who are spoken ill of by other workers or supervisors. \\
\hline 19 & $\begin{array}{l}\text { Inspire employees to complete urgent tasks at hand, if possible, even outside normal working } \\
\text { hours. }\end{array}$ \\
\hline 20 & $\begin{array}{l}\text { Inspire employees to take time to coach and mentor other co-workers to excel in successfully } \\
\text { completing tasks. }\end{array}$ \\
\hline \multicolumn{2}{|r|}{ Influence of distributive justice on reputable employee retention: Management should... } \\
\hline 21 & Recognise and reward employees with integrity. \\
\hline 22 & Encourage employees to be actively concerned about stakeholders' interests. \\
\hline 23 & Train employees to strictly comply with legal and professional standards when executing their jobs. \\
\hline 24 & Offer sufficient flexibility to allow employees to reconcile their personal lives with their jobs. \\
\hline 25 & Offer various career advancement opportunities in doing expected tasks. \\
\hline
\end{tabular}

\section{Contributions of the research}

Some of the contributions of this study relevant to this article are identified below.

- The findings of this study have contributed to the body of knowledge in financial services literature in South Africa by developing a theoretical model of organisational justice, and specifically distributive justice, for this article.

- The study has made a unique contribution to the field of organisational justice as, for the first time in the literature, it has identified two aspects of measuring organisational justice perceptions, namely procedural-interactional justice and distributive justice (focus of this article).

- The findings can inform financial services firms about financial services policy formulations so as to assist with the implementation of distributive justice practices.

- The study has provided useful and practical guidelines to organisations so as to ensure effective strategising and management of distributive justice that could enhance their local and global competitiveness and long-term survival. 


\section{Limitations of the study}

Limitations include the following:

- The limited sample is acknowledged, focusing on only four provinces in South Africa. Further studies could include other provinces as well.

- The structured closed-ended nature of the questionnaire could have limited the opinions of the respondents.

- The public financial services, such as Auditor General, were not considered.

- Employees who advocate fairness may have responded more readily than others, thus resulting in sample bias.

\section{References}

Ajmal, A., Abrar, M., Bashir, M., Khan, M. \& Sagib, S. (2015). The effects of intrinsic and extrinsic rewards on employee attitudes: Mediating role of perceived organisational support. Journal of Science and Management, 8(4):461-476. https://doi.org/10.4236/jssm.2015.84047

Al-Tit, A.A. \& Hunitie, M. (2015). The mediating effect of employee engagement between its antecedents and consequences. Journal of Management Research, 7(5):47-62. https://doi.org/10.5296/jmr.v7i5.8048

Anik, L., Aknin, L.B., Norton, M.I. \& Dunn, E.W. (2009). Feeling good about giving: The benefits (and costs) of self-interested charitable behavior. Harvard Business School Marketing Unit Working Paper No. 10-012. https://doi.org/10.2139/ssrn.1444831

Baer, M., Cummings, A. \& Oldham, G.R. (2003). Reward creativity: When does it really matter? The Leadership Quarterly, 14(1):569-586. https://doi.org/10.1016/S1048-9843(03)00052-3

Bikhani, N. (2017). The role of financial services in society. The South African Insurance Industry Survey 2107. Johannesburg: KPMG. 19-24.

Botha, C. (2015). Sharing insight on key industry issues. The Southern Africa Financial Services Journal. New York: PricewaterhouseCoopers.

Butt, S. \& Atif, M. (2015). Exploring the role of organisational justice as an antecedent of psychological ownership. Transactions on Education and Social Sciences, 7(1):36-50.

Buys, P.W. \& Van Niekerk, E. (2014). The South African financial services industry's integrated reporting compliance with global reporting initiative framework. Bank and Bank System, 9(4):107-115.

Carter, M.Z., Mossholder, K.W. \& Harris, J.N. (2018). Congruence effects of contingent reward leadership intended and experienced on team effectiveness: The mediating role of distributive justice climate. Journal of Occupational and Organizational Psychology, 91(3):465-485. https://doi.org/10.1111/joop.12210

Chory, R.M. \& Hubbell, A.P. (2008). Organizational justice and managerial trust as predictors of antisocial employee responses. Communication Quarterly, 56(4):357-375. https://doi.org/10.1080/01463370802448121

Cojocaru, D.N. \& Stoican, C. (2010). Diagnosis of organisational climate as mean of management of communication. International Journal of Administration, 19(1):5-26.

Coldwell, D.A.L. \& Perumal, S. (2007). Perceptions of the measurability, importance and effects of work equity on job satisfaction and work motivation: An exploratory study of the utility of equity theory. Alternation, 14(1):197-217.

Colquitt, J.A. \& Rodell, J.B. (2011). Justice, trust and trustworthiness: A longitudinal analysis integrating the theoretical perspective. Academy of Management Journal, 54(6):1183-1206. https://doi.org/10.5465/ amj.2007.0572

Colquitt, J.A. \& Zipay, K.P. (2015). Justice, fairness and employee reactions. Annual Review of Organizational Psychology and Organizational Behavior, 2:11.1-11.25. https://doi.org/10.1146/annurevorgpsych-032414-111457 
Cooper, C.L., Cartwright, S. \& Earley, P.C. (2001). The international handbook of organisational culture and climate. Chichester: Wiley.

Crawshaw, J.R., Cropanzano, R., Bell, C.M. \& Nadisic, T. (2013). Organizational justice: New insights from behavioural ethics. Human Relations, 66(7):885-904. https://doi.org/10.1177/0018726713485609

Cropanzano, R. \& Ambrose, M.L. (2001). Procedural and distributive justice are more similar than you think: $A$ Monistic perspective and a research agenda. California: Stanford University Press. 119-151.

Cropanzano, R., Bowen, D.E. \& Gilliland, S.W. (2007). The management of organisational justice. Academy of Management Perspectives, 21(4):34-48. https://doi.org/10.5465/amp.2007.27895338

Cropanzano, R. \& Greenberg, J. (1997). Progress in organisational justice: Tunnelling through the maze. New York: John Wiley \& Sons.

De Cremer, D., Mayer, D. \& Schminke, M. (2010). On understanding ethical behaviour and decision making: A behavioural business ethics approach. Business Ethics Quarterly, 20(1):1-6. https://doi.org/10.5840/ beq20102012

Drahos, P. (2017). Regulatory theory: Foundations and applications. Action: Australian National University Press.

Dutton, J.E. \& Ragins, B.R. (2017). Exploring positive relationships at work. London: Routledge. https://doi.org/ $10.4324 / 9781315094199$

Festinger, L.A. (1954). A theory of social comparison processes. Human Relations, 7(2):117-140. https://doi.org/ $10.1177 / 001872675400700202$

Gomes, E., Mellahi, K., Sahadev, S. \& Harvey, A. (2017). Perceptions of justice and organisational commitment in international mergers and acquisitions. International Marketing Review, 34(5):582-605. https://doi.org/ 10.1108/IMR-02-2014-0046

Greenberg, J. \& Baron, R.A. (2008). Behaviour in organisations. 7th edition. New Jersey: Prentice Hall.

Haliru, M. \& Mokhtar, S.S.M. (2015). The mediating effect of perceived safety and trust on the relationship between perceived justice and customer loyalty in the Nigerian airline industry. International Journal of Management Sciences and Business Research, 4(10):1-7.

Hatfield, E., Salmon, M. \& Rapson, R.L. (2011). Equity theory and social justice. Journal of Management, Spirituality \& Religion, 8(2):101-121. https://doi.org/10.1080/14766086.2011.581818

Hausknecht, J., Rodda, J.M. \& Howard, M.J. (2009). Targeted employee retention. Performance based and job related differences in reported reasons for staying. Human Resources Management, 48(2):269-288. https://doi.org/10.1002/hrm.20279

Haydin, M. (2018). The notion of equality. New York: Routledge. https://doi.org/10.4324/9781315199795

Homans, G.C. (1961). Social behaviour: Its elementary forms. London: Routledge \& Kegan Paul.

Kang, D. (2007). Perceived organisational justice as predictor of employee motivation to participate in training. Research and Practise in Human Resources Management, 15(1):89-107.

Khan, I., Shahid, M., Nawab, S. \& Wali, S.S. (2013). Influence of intrinsic and extrinsic rewards on employee performance: The banking sector of Pakistan. Academic Research International, 4(1):282-291.

Kim, W. \& Park, J. (2017). Examining structural relationships between work engagement, organizational procedural justice, knowledge sharing, and innovative work behavior for sustainable organizations. Sustainability, 9(2). https://doi.org/10.3390/su9020205

Konovsky, M.A. \& Pugh, S.D. (1994). Citizenship behaviour and social exchange. Academy Management Journal, 37(1):656-669. https://journals.aom.org/doi/10.5465/256704

Lamont, J. (2017). Distributive justice. London: Routledge. https://doi.org/10.4324/9781315257563

Lather, A.S. \& Kaur, S. (2017). Proceedings of international conference on strategies in volatile and uncertain environment for emerging markets. New Delhi: Indian Institute of Technology, 14-15 July 2017.

Lavelle, J.J., Rupp, D.E. \& Brockner, J. (2007). Taking a multi-foci approach to the study of justice, social exchange and citizenship behaviour: The target similarity model. Journal of Management, 33(1):841-866. https://doi.org/10.1177/0149206307307635 
Ledimo, O. (2015). Development and validation of an organisational justice measurement instrument for a South African context. Risk Governance \& Control: Financial Markets \& Institutions, 5(1):27-38. https://doi.org/ $10.22495 /$ rgcv5i1art3

Leventhal, G.S., Karuza, J. \& Fry, W.R. (1980). Beyond fairness: A theory of allocation preferences. In: G. Mikula (ed.). Justice in social interaction. New York: Springer-Verlag.

Lown, C.S., Osler, C.L., Strahan, P.E. \& Sufi, M. (2000). The changing landscape of the financial services industry. What lies ahead? FRB of New York Economic Policy Review, 6(4):39-55.

Maiese, M. (2013). Distributive justice: Beyond intractability. Colorado: University of Colorado.

Markos, S. \& Sridevi, M. (2010). Employee engagement: The key to improving performance. International Journal of Business Management, 5(12):89-96. https://doi.org/10.5539/ijbm.v5n12p89

Martins, N. \& Von der Ohe, H. (2003). Organisational climate measurement - new and emerging dimensions during a period of transformation. South African Journal of Labour Relations, 27(3/4):41-58.

Moliner, C, Cropanzano, R \& Martínez-Tur, V. (2017). Organizational justice: International perspectives and conceptual advances. Oxon: Routledge. https://doi.org/10.4324/9781315648194

Morsing, M. \& Schultz, M. (2006). Corporate social responsibility communication: Stakeholder information, response and involvement strategies. Business Ethics: A European Review, 15(4):323-338. https://doi.org/ 10.1111/j.1467-8608.2006.00460.x

Muchinsky, P.M. (2003). Psychology applied to work. Belmont: Thomson Learning.

Nandan, T. \& Azim, A.M.M. (2015). Organizational justice and organizational citizenship behaviour: The mediating role of psychological capital. American International Journal of Social Science, 4(6):148-156.

Neuman, W.L. (2003). Social research methods: Qualitative and quantitative approaches. 5th edition. Boston: Pearson.

Niehoff, B.P. \& Moorman, R.H. (2010). Does perceived support mediate the relationship between procedural justice and organisational citizenship behaviour? Academy of Management Journal, 41(3):351-357. https://doi.org/10.5465/256913

Noordin, F., Omar, S., Sehan, S. \& Idrus, S. (2010). Organisational climate and its influence on organisational commitment. International Business and Economics Research Journal, 9(2):1-10. https://doi.org/10.19030/ iber.v9i2.516

Nwokocha, I. \& Iheriohanma, E.B.J. (2012). Emerging trends in employee retention strategies in a globalizing economy: Nigeria in focus. Asian Social Science, 8(10):198-207. https://doi.org/10.5539/ass.v8n10p198

O'Brien M. (2017). Social work and the practice of social justice: An initial overview. Aotearoa New Zealand Social Work, 21(1-2):1-10.

Ololube, N.P. (2016). Handbook of research on organizational justice and culture in higher education institutions. Hersey: Information Science Reference. https://doi.org/10.4018/978-1-4666-9850-5

Organ, D.W., Podsakoff, P.M. \& Mackenzie, S.B. (2006). Organizational citizenship behavior: Its nature, antecedents, and consequences. Thousand Oaks, CA: SAGE.

Pettigrew, A.M.(2014). The politics of organisational decision-making. Oxon: Routledge. https://doi.org/10.4324/ 9781315824116

Rani, R., Garg, P. \& Rastogi, R. (2012). Organizational justice and psychological wellbeing of police employees: A relationship study. International Journal of Advances in Management and Economics, 1(5):183-194.

Rawlins, B. (2008). Measuring the relationship between organizational transparency and employee trust. Public Relations Journal, 2(2):1-21. https://doi.org/10.1080/10627260802153421

Reiche, B.S., Cardona, P., Lee, Y.T. \& Canela, M. (2014). Why do managers engage in trustworthy behavior? A multilevel cross-cultural study in 18 countries. Personnel Psychology, 67(1):61-98. https://doi.org/ 10.1111 peps. 12038

Resher, N. (2018). Fairness: Theory and practice of distributive justice. New York: Routledge.

Rhoades, L. \& Eisenberg, R. (2002). Perceived organisational support: A review of literature. Journal of Applied Psychology, 87(4):698-714. https://doi.org/10.1037/0021-9010.87.4.698 
Roy, S.K., Devlin, J.F. \& Sekhon, H. (2015). The impact of fairness on trustworthiness and trust in banking. Journal of Marketing Management, 31(10):996-1017. https://doi.org/10.1080/0267257X.2015.1036101

Rubina, Y, Umar, F. \& Fahad, A. (2013). Impact of reward on organizational performance: Empirical evidence from telecom sector of Pakistan. Journal of Basic and Applied Scientific Research, 3(5):938-946.

Rupp, D.E. (2011). An employee-cantered model of organisational justice and social responsibility. Organisational Psychology Review, 1(1):72-94. https://doi.org/10.1177/2041386610376255

Rupp, D.E., Wright, P.M., Aryee, S. \& Luo, Y. (2015). Organizational justice, behavioral ethics, and corporate social responsibility: Finally the three shall merge. Management and Organization Review, 11(1):15-24. https://doi.org/10.1017/mor.2015.8

Samuel, M.O. \& Chipunza, C. (2009). Employee retention and turnover: Using motivational variables as panacea. African Journal of Business Management, 3(8):410-415.

Saunders, M.N.K. \& Thornhill, A. (2003). Organizational justice, trust and the management of change. An exploration. Personnel Review, 32(3):360-375. https://doi.org/10.1108/00483480310467660

Schnakenberg, A.K. \& Tomlinson, E.C. (2016). Organizational transparency: A new perspective on managing trust in organisation-stakeholder relationships. Journal of Management, 42(7):1784-1810. https://doi.org/ $10.1177 \% 2 \mathrm{~F} 0149206314525202$

Shah, N., Anwar, S. \& Irani, Z. (2017). The impact of organisational justice on ethical behaviour. International Journal of Business Innovation and Research, 12(2):240-258. https://doi.org/10.1504/IJBIR.2017.10001664

Sjahruddin, H., Sudiro, A.A. \& Normijati, L.D. (2013). Organisational justice, organisational commitment and trust in manager as predictor of organisational citizenship behaviour. Interdisciplinary Journal of Contemporary Research in Business, 4(12):133-141.

Smit, P.J. \& Cronje, D.J. (2002). Management principles: A contemporaryedition for Africa. London: McGraw Hill.

Snelgar, R.J., Renard, M. \& Venter, D. (2013). An empirical study of the reward preferences of South African employees. SA Journal of Human Resource Management/SA Tydskrif vir Menslikehulpbronbestuur, 11(1):84-97. https://doi.org/10.4102/sajhrm.v11i1.351

Srivastava, U.R. (2015). Multiple dimensions of organizational justice and work-related outcomes among health-care professionals. American Journal of Industrial and Business Management, 5:666-685. https://doi.org/10.4236/ajibm.2015.511067

StatsSA. (2017). Economic sectors that contribute to South Africa's GDP: Q3 2017. Pretoria: Statistics South Africa.

Sturges, P. (2007). What is this absence called transparency? Proceedings of the International Center for Information Ethics (ICIE) Conference. Pretoria, South Africa. 5-7 February.

Taran, P. \& Gächter, A. (2012). Achieving equality in intercultural workplaces. Dublin: Irish Human Rights and Equality Commission.

Thompson, N. (2018). Promoting equality. London: Palgrave.

Treviño, K.L., Butterfield, K.D. \& McCabe, D.L. (2001). The ethical context in organizations: Influences on employee attitudes and behaviors. In: J. Dienhart, D. Moberg \& R. Duska (eds.). The next phase of business ethics: Integrating psychology and ethics. (Research in Ethical Issues in Organizations, Volume 3). Bingley, UK: Emerald Group Publishing. 301-337. https://doi.org/10.1016/S1529-2096(01)03018-8

Trevińo, L.K., Weaver, G.R. \& Reynolds, S.J. (2006). Behavioural ethics in organisations: A review. Journal of Management, 32(6):951-990. https://doi.org/10.1177/0149206306294258

Veloso, E.F.R., Da Silva, R.C., Dutra, J.S., Fischer, A.L. \& Trevisan, L.N. (2014). Talent retention strategies in different organizational contexts and intention of talents to remain in the company. Journal on Innovation and Sustainability, (1):49-61. https://doi.org/10.24212/2179-3565.2014v5i1p49-61

Versosa, C.C. \& Garcia, H.R. (2009). Building commitment to reform through strategic communication: The five key decisions. Washington: The World Bank. https://doi.org/10.1596/978-0-8213-7621-8

Wan, H.L. (2017). Relationship between organisational justice and organisational citizenship behaviour: Examining the mediating role of job satisfaction. In: Management and Organization: Concepts, Tools and Applications. Harlow, MA: Pearson. 77-97. https://doi.org/10.18515/dBEM.M2017.n02.ch07 
Wayne, S.J., Shore, L.M., Bommer, W.H. \& Tetrick, L.E. (2002). The role of fair treatment and rewards in perceptions of organisational support and leader-member exchange. Journal of Applied Psychology, 87(1):590-598. https://doi.org/10.1037/0021-9010.87.3.590

Whiteside, D.B. (2015). Promoting fairness in the workplace: Identifying and overcoming the barriers to managerial fairness in organizations. Waterloo: Wilfrid Laurier University.

Yasmeen, R., Farooq, U. \& Asghar, F. (2013). Impact of rewards on organizational performance: Empirical evidence from Telecom Sector of Pakistan, Journal of Basic and Applied Scientific Research, 3(5):938-946.

Yean, T.F. \& Yusof, A.A. (2016). Organizational justice: A conceptual discussion. Procedia: Social and Behavioral Sciences, 219:798-803. https://doi.org/10.1016/j.sbspro.2016.05.082 